\title{
Genetic Relatedness of African and United States Populations of Cercospora zeae-maydis
}

\author{
Larry D. Dunkle and Morris Levy
}

First author: Crop Production and Pest Control Research, U.S. Department of Agriculture-Agricultural Research Service, Department of Botany and Plant Pathology, Purdue University, West Lafayette, IN 47907-1155; second author: Department of Biology, Purdue University, West Lafayette, IN 47907-1392.

Accepted for publication 2 February 2000.

\begin{abstract}
Dunkle, L. D., and Levy, M. 2000. Genetic relatedness of African and United States populations of Cercospora zeae-maydis. Phytopathology 90:486-490.

Two taxonomically identical but genetically distinct sibling species, designated groups I and II, of Cercospora zeae-maydis cause gray leaf spot of maize in the United States. Isolates of the gray leaf spot pathogen from Africa were compared with isolates from the United States by amplified fragment length polymorphism (AFLP) analysis and restriction digests of internal transcribed spacer (ITS) regions and 5.8S ribosomal DNA (rDNA), as well as by morphological and cultural characteristics. The isolates from Africa were morphologically indistinguishable from the U.S. isolates in both groups, but like isolates of group II, they grew more slowly and failed to produce detectable amounts of cercosporin in culture. Analysis of restriction fragments from the ITS and rDNA regions

which is more prevalent in the United States and other parts of the world. Cluster analysis of 85 AFLP loci confirmed that the African and U.S. group II populations were conspecific (greater than $97 \%$ average similarity) with limited variability. Among all group II isolates, only 8 of 57 AFLP loci were polymorphic, and none was specific to either population. Thus, although gray leaf spot was reported in the United States several decades prior to the first record in Africa, the relative age of the two populations on their respective continents could not be ascertained with confidence. The absence of $C$. zeae-maydis group I in our samples from four countries in the major maize-producing region of Africa as well as the greater AFLP haplotype diversity found in the African group II population, however, suggest that Africa was the source of C. zeae-maydis group II in the United States. The overall paucity of AFLP variation in this sibling species further suggests that its origin is recent or that the ancestral population experienced a severe bottleneck prior to secondary migration.
\end{abstract} digested with five endonucleases indicated that all of the African isolates shared the profile of the C. zeae-maydis group II population from the eastern United States and, thus, are distinct from the group I population,
Additional keywords: population genetics.
Gray leaf spot, caused by Cercospora zeae-maydis Tehon \& E. Y. Daniels, is the most common and destructive foliar disease of maize in North America. The disease and pathogen were first reported in 1925 in southern Illinois (13) and have become widely distributed across the United States during the last two decades, concomitant with increases in reduced tillage practices and monoculture of maize (6). Gray leaf spot was not recorded in Africa until 1988, when it was observed in South Africa (15) and, since then, has spread rapidly northward into the major maize-growing regions of the continent (17). Estimates of yield losses attributed to gray leaf spot in South Africa are frequently as high as 50 to $65 \%$ for moderately resistant and susceptible hybrids, respectively (16). Most maize hybrids are susceptible to the pathogen despite extensive attempts to incorporate effective resistance into commercially available hybrids.

Recent studies of genetic variability in C. zeae-maydis indicated that the pathogen population in the United States consists of two taxonomically identical, partially sympatric groups that are genetically distinct (14) and, thus, are considered sibling species in accord with the definition and descriptions by Mayr (8,9). Al-

Corresponding author: L. D. Dunkle; E-mail address: dunkle@btny.purdue.edu

Names are necessary to report factually on available data. However, the USDA neither guarantees nor warrants the standard of the product, and the use of a name implies no approval of the product to the exclusion of others that may also be suitable.

Publication no. P-2000-0313-02R

This article is in the public domain and not copyrightable. It may be freely reprinted with customary crediting of the source. The American Phytopathological Society, 2000. though isolates within both groups exhibit a range of aggressiveness when inoculated on maize hybrids, disease symptoms incited by isolates from both groups are identical, and neither group differs significantly from the other in the severity of disease incited on individual hybrids (4). Thus, the substantial genetic distance between the two groups in the United States was not expressed as differential virulence on a limited sample of maize germ plasm.

To effectively control gray leaf spot by discovery and incorporation of genetic resistance, the composition and genetic variability of the pathogen population must be characterized. The objectives of our study were to determine the composition of the $C$. zeae-maydis population in Africa and its relationship to the sibling species that occur in the United States. The genetic distance separating group I and II isolates in the United States (14) suggests that these sibling species did not originate in the same location and that one species was not the immediate ancestor of the other. A principal issue is whether the African population of the gray leaf spot pathogen is ancestral to or derivative of the U.S. population. Based primarily on chronological information, Ward et al. (17) suggested that the pathogen was introduced into Africa with infested residue in maize imported from the United States during the 1980s. Our results provide no evidence to support this hypothesis and are consistent with the alternative possibility that Africa was the source of C. zeae-maydis group II in the United States.

\section{MATERIALS AND METHODS}

Disease samples and fungal cultures. Maize leaves with gray leaf spot symptoms were collected during June and July 1998 by 
K. Pixley (International Maize and Wheat Improvement Center [CIMMYT], Mexico D.F.) and M. Caulfield (Seed Co. Ltd., Harare, Zimbabwe) from three fields (designated A to $\mathrm{C}$ in Table 1) at two locations near Harare, Zimbabwe, and by G. Bigirwa, D. Kyetere, and J. Imanywoha (Namulonge Agricultural Research Organization, Namulonge, Uganda) from four locations in Uganda. Additional samples were collected by G. Odvody (Texas A\&M University, Corpus Christi) during April 1999 from Pietermaritzberg, South Africa, and Lusaka, Zambia. At least two lesions from 5 to 10 leaves at each location were surface-sterilized and incubated in the light for 2 to 3 days until conidiophores bearing conidia emerged from stromatal tissue beneath leaf stomata. The dimensions of at least 50 conidia and 25 conidiophores each from 7 to 10 lesions were measured with an ocular micrometer, and characteristics of the conidia and conidiophores were recorded. Conidia were removed from several fascicles of conidiophores within each lesion, placed in a vial of sterile water, and distributed on the surface of potato dextrose agar (PDA; Difco Laboratories, Detroit). After growth for 2 to 3 days, individual colonies arising from single conidia were transferred to both dilute $(0.2 \times)$ PDA and V8-juice agar to assess cercosporin production and obtain conidia, respectively $(1,5)$.

Production of cercosporin was tested by spectrophotometric analysis of $5 \mathrm{~N} \mathrm{KOH}$ or acetone extracts of a cylinder taken with a 5-mm cork borer through the mycelium and underlying medium (5). A group I isolate, USIN-12, was used as a positive standard. Mycelium for preparation of DNA was harvested by filtration after growth for 10 to 14 days in modified Fries' medium (10) in Erlenmeyer flasks on a rotary shaker at $24^{\circ} \mathrm{C}$ and was frozen at $-80^{\circ} \mathrm{C}$ until used.

TABLE 1. Isolates of Cercospora zeae-maydis analyzed in this study

\begin{tabular}{|c|c|}
\hline Isolate & Origin \\
\hline USIN-12 & Gibson County, IN \\
\hline USNC-4 & Laurel Springs, NC \\
\hline USNY-2 & Chemung, NY \\
\hline USOH-1 & Apple Creek, OH \\
\hline USOH-4 & Howard, $\mathrm{OH}$ \\
\hline USOH-7 & Loudonville, $\mathrm{OH}$ \\
\hline USOH-8 & Wooster, $\mathrm{OH}$ \\
\hline USPA-4 & Oley, PA \\
\hline USVA-2 & Wyeth County VA \\
\hline USVA-3 & Montgomery County, VA \\
\hline UG-1 & Iganga, Uganda \\
\hline UG-2 & Iganga, Uganda \\
\hline UG-3 & Iganga, Uganda \\
\hline UG-4 & Iganga, Uganda \\
\hline UG-5 & Kamengo-Mpigi, Uganda \\
\hline UG-6 & Kamengo-Mpigi, Uganda \\
\hline UG-7 & Kamengo-Mpigi, Uganda \\
\hline UG-8 & Namulonge, Uganda \\
\hline UG-9 & Namulonge, Uganda \\
\hline UG-10 & Namulonge, Uganda \\
\hline UG-11 & Namulonge, Uganda \\
\hline UG-12 & Tororo, Uganda \\
\hline UG-13 & Tororo, Uganda \\
\hline UG-14 & Tororo, Uganda \\
\hline UG-15 & Tororo, Uganda \\
\hline ZM-1 & Harare (A), Zimbabwe \\
\hline ZM-2 & Harare (A), Zimbabwe \\
\hline ZM-3 & Harare (A), Zimbabwe \\
\hline ZM-4 & Harare (A), Zimbabwe \\
\hline ZM-5 & Harare (A), Zimbabwe \\
\hline ZM-6 & Harare (A), Zimbabwe \\
\hline ZM-7 & Harare (A), Zimbabwe \\
\hline ZM-8 & Harare (B), Zimbabwe \\
\hline ZM-9 & Harare (B), Zimbabwe \\
\hline ZM-10 & Harare (B), Zimbabwe \\
\hline ZM-11 & Harare (B), Zimbabwe \\
\hline ZM-12 & Harare (B), Zimbabwe \\
\hline ZM-13 & Harare (B), Zimbabwe \\
\hline ZM-14 & Harare (B), Zimbabwe \\
\hline ZM-15 & Harare (C), Zimbabwe \\
\hline
\end{tabular}

Analysis of genetic variation. DNA was extracted from frozen mycelia by the hexadecyltrimethylammonium bromide (CTAB) method $(12,19)$ and quantified by spectrophotometry. Genetic variation among 1 isolate of $C$. zeae-maydis group I and 9 isolates of C. zeae-maydis group II from the United States (14), 15 isolates from Uganda, and 15 isolates from Zimbabwe was evaluated by amplified restriction fragment length polymorphism (AFLP), as described previously (14), with ${ }^{33} \mathrm{P}$-labeled EcoRI primer plus A and MseI primer plus CA in the selective amplification step. Genetic similarities among isolates were evaluated (7) from pairwise comparisons of shared AFLP loci between 50 and 500 nucleotides and a phenetic cluster analysis of all pairwise data by the unweighted pair group method with arithmetic averaging, as described previously (14).

For analysis of internal transcribed spacer (ITS) regions and 5.8S ribosomal DNA (rDNA), genomic DNAs from all isolates listed in Table 1 plus three each from South Africa and Zambia were amplified by polymerase chain reaction (PCR) with primers ITS4 and ITS5 (18), purified by extraction with chloroform and precipitation with ethanol, and digested with restriction endonucleases $B f a \mathrm{I}$, HaeII, HhaI, MseI, and TaqI (New England Biolabs, Inc., Beverly, MA). Digestion products of ITS regions from all isolates were separated by electrophoresis on $2 \%$ agarose gels and compared with the fragment sizes predicted from the ITS and 5.8S rDNA sequence of C. zeae-maydis group II isolates as previously determined (14).

\section{RESULTS}

Morphological and cultural characteristics. Conidia produced on gray leaf spot lesions obtained from the African samples ranged from 6 to $10 \mu \mathrm{m}$ wide and 56 to $86 \mu \mathrm{m}$ long with mean dimensions of $7.7 \times 65.3 \mu \mathrm{m}$. They were hyaline, straight to very slightly curved, and obclavate and contained 5 to 14 septa with a mean and mode of 8 . Conidiophores were olivaceous, slightly flexuous and were produced in fascicles of 8 to 20 . They ranged in size from 5 to $7.5 \times 50$ to $125 \mu \mathrm{m}$, with mean dimensions of $6 \times 114$ $\mu \mathrm{m}$, and contained two to five septa. Thus, the primary taxonomic characters of the isolates from Africa were similar to those of isolates from the United States (14) and consistent with the descriptions of $C$. zeae-maydis $(3,6,13)$.

Within the lesions, the pathogen produced partially embedded, globose spermogonia-like structures that were enclosed by darkly

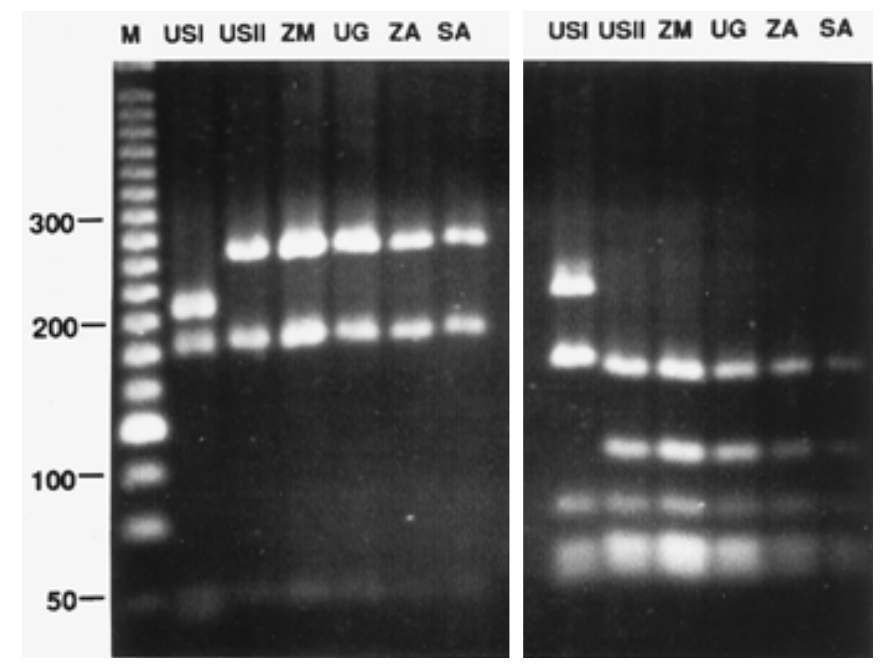

Fig. 1. Identification of African isolates of Cercospora zeae-maydis as members of group II based on digestion of internal transcribed spacer regions and 5.8S ribosomal DNA with restriction enzymes $M s e \mathrm{I}$ (left) or TaqI (right) followed by electrophoretic separation of digestion products on an agarose gel. Digestion products of $C$. zeae-maydis group I from Indiana (USI), C. zeaemaydis group II from North Carolina (USII), and representative isolates from Zimbabwe (ZM), Uganda (UG), Zambia (ZA), and South Africa (SA) are shown. Lane M, markers; sizes in base pairs shown to the left. 
pigmented cells. A gray mass of single, hyaline, rod-shaped cells measuring $\approx 1.5 \times 5 \mu \mathrm{m}$ exuded from the apex. These cells could not be induced to germinate on a variety of media and, thus, resemble spermatia of ascomycetous fungi.

In culture on a variety of media, all isolates from Africa grew at a substantially slower rate than isolates of $C$. zeae-maydis group I, the predominant group in the United States, but comparable to the linear growth rate of isolates of $C$. zeae-maydis group II from the eastern United States (14). On PDA in the light at $24^{\circ} \mathrm{C}$, the African and group II isolates grew $\approx 4$ to $5 \mathrm{~mm} /$ week compared with 8 to $12 \mathrm{~mm} /$ week for C. zeae-maydis group I isolates.

Isolates were grown on dilute PDA in the light to detect cercosporin. Isolates of $C$. zeae-maydis group I produced abundant cercosporin, but the isolates from Africa and the group II isolates

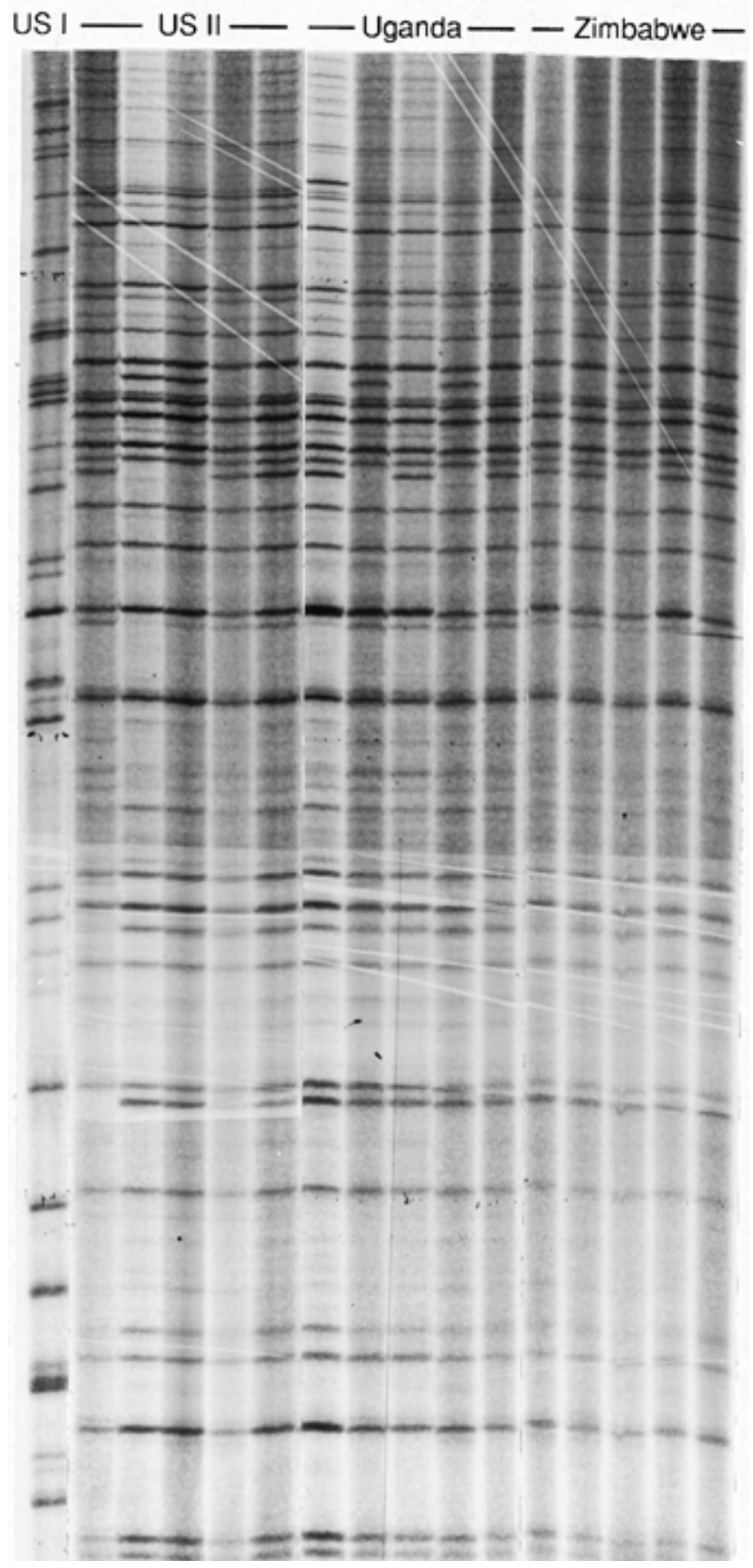

Fig. 2. Amplified fragment length polymorphism profiles of five monoconidial isolates of Cercospora zeae-maydis group II from gray leaf spot lesions collected in the eastern United States (USII), Uganda, and Zimbabwe. A representative isolate of C. zeae-maydis group I (USI) is included for comparison. from the eastern United States did not produce detectable quantities over a period of 3 weeks in culture (data not shown). Occasionally, the mycelium of a few African isolates accumulated a light pink pigment that was not secreted into the surrounding medium. The absorption spectra of the pigment in these cultures, extracted with either acetone or $\mathrm{KOH}$, were not characteristic of cercosporin in those solvents.

Analysis of the ITS and rDNA regions. The two sibling species of C. zeae-maydis in the United States can be differentiated by digestion of the ITS and rDNA region with TaqI and MseI (14). Isolates from Africa were analyzed by restriction fragment length polymorphism (RFLP) analysis of the ITS region to establish their affinities with group I or II. The TaqI and MseI restriction fragments of representative isolates from the United States and four African countries are shown in Figure 1. The digestion products from all of the African isolates were identical to those from group II isolates obtained from the United States and distinct from isolates of group I.

Electrophoretic analysis of the restriction fragments of ITS and rDNA from the 36 African isolates and the 9 group II isolates from the United States digested with three additional endonucleases (BfaI, HaeII, and HhaI) indicated that the restriction sites are conserved in all isolates (data not shown). All of these digestion patterns were monomorphic, further indicating genetic homology and taxonomic identity among the isolates from Africa and C. zeae maydis group II from the United States.

Analysis of genetic relatedness. AFLP profiles of the isolates from Uganda and Zimbabwe were remarkably similar to those of the U.S. group II isolates and distinctly different from the representative member of $C$. zeae-maydis group I included in the analysis (Fig. 2). Genetic diversity within both the African population and the U.S. group II population was limited; the average within population similarity was 97.6 and $98.8 \%$, respectively (Table 2). The average similarity between both group II populations was equally high at $97.6 \%$. Most (49 of 57) AFLP loci were monomorphic in both populations, and all 8 loci that were polymorphic in one population also were polymorphic in the other. The extent of similarity among members of the two populations is evident in the phenogram shown in Figure 3. Significantly, neither population clustered separately, and both populations shared 4 of 19 very similar haplotypes. Consequently, despite their geographic isolation, the two populations are clearly conspecific. The only genetic distinction between them was that AFLP haplotype diversity in the form of private (unshared) haplotypes was disproportionately higher in the African sample (13 of 17) compared with the eastern U.S. sample (2 of 6) (Table 2)

\section{DISCUSSION}

We analyzed isolates of the gray leaf spot pathogen from four African countries separated by more than $3,000 \mathrm{~km}$, a distance greater than the distance across the U.S. corn belt and representing the major maize-growing region of Africa. Based on morphological characteristics and molecular genetic criteria, the African

TABLE 2. Amplified fragment length polymorphism diversity in Cercospora zeae-maydis group II isolates

\begin{tabular}{lcc}
\hline & U.S. isolates & African isolates \\
\hline No. of isolates analyzed & 9 & 30 \\
No. of loci scored & 57 & 57 \\
No. of polymorphic loci & 8 & 8 \\
Average similarity (\%) & & \\
$\quad$ versus group I & 41.4 & 42.8 \\
$\quad$ versus U.S. group II & 98.8 & 97.6 \\
$\quad$ versus African group II & 97.6 & 97.6 \\
No. of haplotypes & 6 & 17 \\
No. of unique haplotypes & 2 & 13 \\
\hline
\end{tabular}


population of $C$. zeae-maydis is equivalent to the eastern U.S. population of $C$. zeae-maydis, previously designated group II (14). Thus, the two group II populations comprise a sibling species (sensu Mayr [8,9]) of C. zeae-maydis group I. Although the isolates from Africa and the eastern United States are taxonomically identical to C. zeae-maydis group I based on conidial and conidiophore characteristics, they are distinguished from group I by physiological characteristics, such as slower growth rate and inability to produce cercosporin in culture.

The genetic similarity between $C$. zeae-maydis groups I and II determined by AFLP analysis with one primer pair was $\approx 40 \%$ (Table 2 ), somewhat higher than the $\approx 20 \%$ previously reported (14) based on analyses of 91 isolates with 2 AFLP primer pairs. Regardless of the precise value, the large genetic distance separating groups I and II is consistent with the suggestion of divergent biological and spatial origins of these sibling species. Although no rigorous phylogenetic analysis has been attempted, comparative AFLP diversity (14) placed C. zeae-maydis group II somewhat less distant from C. kikuchii (a soybean pathogen) and C. sorghi (a sorghum pathogen) than from its ecologically parallel sibling species of presumed origin in North America.

On the other hand, the extent of genetic similarity between the African and eastern U.S. populations of C. zeae-maydis group II is remarkably high considering their physical separation. The average AFLP similarity between the two populations is equivalent to their internal similarity, and there are no private AFLP loci in either population. These observations are in contrast to the results of Borchardt et al. (2) in their studies of the maize pathogen $\mathrm{Se}$ tosphaeria turcica, in which populations from different continents shared no haplotypes and carried several private alleles, resulting in a large genetic distance separating the populations. Consequently, our results suggest that the African and U.S. populations

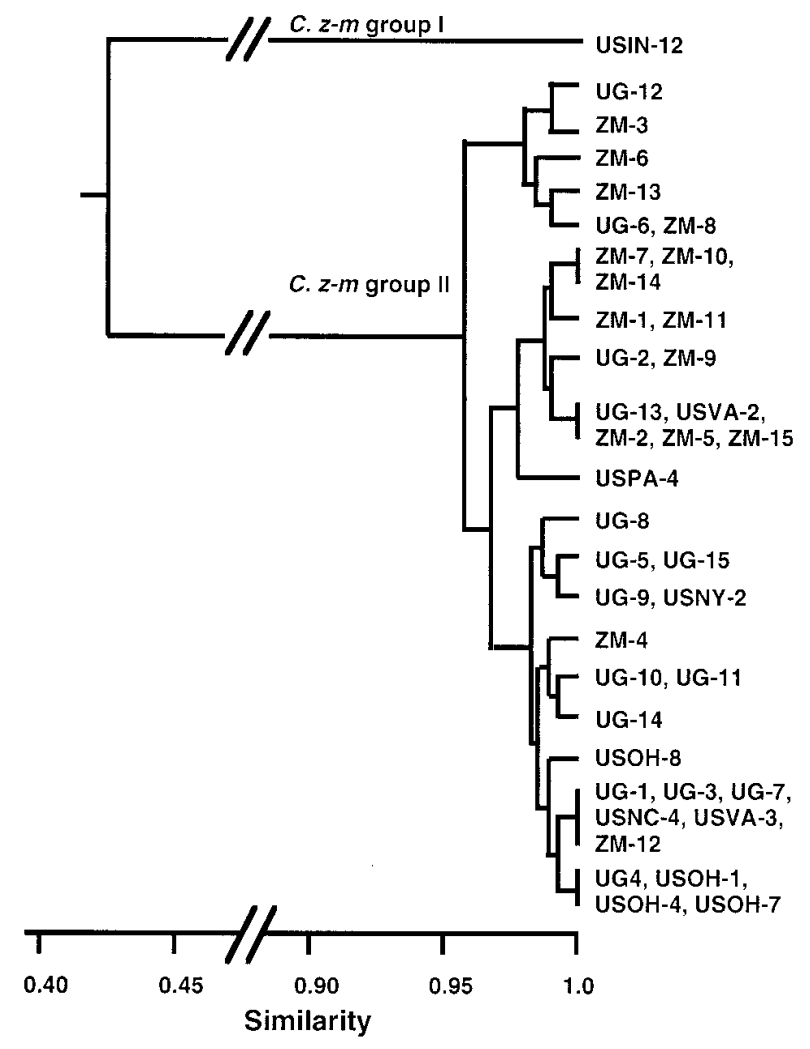

Fig. 3. Unweighted pair group method with arithmetic averaging phenogram of amplified fragment length polymorphism (AFLP) profile variation among isolates of Cercospora zeae-maydis from the eastern United States (US prefix), Uganda (UG), and Zimbabwe (ZM). In all, 85 AFLP loci between 50 and 500 nucleotides were scored in 40 isolates, including one isolate of C. zeaemaydis group I as the outgroup. of C. zeae-maydis group II share a very recent common origin and that one may be the immediate source of the other.

The available data allow some reasonable speculation concerning the sources and mechanisms of intercontinental distribution. Dissemination of the pathogen by atmospheric air currents from continents in different hemispheres is highly unlikely. Even if pathogenic propagules could survive in sufficient quantities to initiate infection, the prevailing winds from North America carry eastward in the northern hemisphere to Europe, while those from southern Africa track westward in the southern hemisphere to South America. Although C. zeae-maydis is not known to be seedborne (10), the pathogen can infect the ear husks and leaf sheaths, which could serve as a source and reservoir of inoculum if sanitation of seed lots is inadequate. Consequently, we suspect that intercontinental migration or movement was directly human assisted.

Because neither population had the greater genetic diversity expected of a well-established ancestral population, conclusions about their relative age and the chronology of continental colonization by $C$. zeae-maydis group II must remain speculative. Gray leaf spot was first recorded in the United States in 1925 and described at epidemic levels since the 1970s (6), whereas the disease was not recorded in South Africa until $1988(15,17)$. However, such chronological information is insufficient to establish the temporal and spatial origins of $C$. zeae-maydis group II because the observation that two sibling species are associated with gray leaf spot is a recent finding (14), and we do not know whether disease samples from the United States prior to 1988 included group II representatives.

Ward et al. (17) proposed that the original source of gray leaf spot inoculum in Africa was from infested residue in maize imported from the United States during the drought years of the early to mid-1980s. However, based on the distribution of the two sibling species in the United States (14), such inoculum would most certainly be composed of $C$. zeae-maydis group I. Yellow dent maize imported for livestock feed would likely contain exclusively group I inoculum if produced in the midwestern United States and predominantly group I inoculum if produced in the eastern United States. White maize imported primarily for human consumption is commonly produced in regions other than the eastern United States, where $C$. zeae-maydis group II occurs. We have detected only $C$. zeaemaydis group II in gray leaf spot samples analyzed from four countries in the maize-growing region of Africa. This, together with the higher frequency of private AFLP haplotypes in the African population of C. zeae-maydis group II, suggests that migration from Africa to the United States is a more tenable scenario.

The possibility remains that both populations were colonized from a third, yet to be identified, source. However, in limited samplings of the gray leaf spot pathogen from other parts of the world, we have found only C. zeae-maydis group I. We analyzed 3 isolates from teosinte and 13 from maize collected in 1998 and 1999 from four locations in Mexico, as well as 2 isolates from China. All of the isolates displayed ITS and rDNA digestion patterns identical to those of the group I representative shown in Figure 1 (data not shown). Furthermore, all of the isolates produced cercosporin in culture and grew at rates comparable to group I isolates. We recognize the additional possibility that the overall paucity of AFLP diversity apparent in group II reflects a severe bottleneck in the ancestral population prior to its more recent, secondary introduction into other regions or continents. Because maize is not native to Africa, the progenitor of $C$. zeae-maydis group II may have originated elsewhere or on another plant species (e.g., sorghum) that is native to Africa and a host to C. sorghi, a related species that is reported to infect maize (3).

\section{ACKNOWLEDGMENTS}

Research reported is a cooperative investigation of the United States Department of Agriculture (USDA)-Agricultural Research Service and 
the Purdue University Agricultural Experiment Station. Published as paper 16080, Purdue University Agricultural Experiment Station. We thank M. McClenning for excellent technical assistance; K. Pixley, G. Bigirwa, and G. Odvody for coordinating collection of maize samples from Africa; and D. Jeffers for maize and teosinte samples from Mexico.

\section{LITERATURE CITED}

1. Beckman, P. M., and Payne, G. A. 1983. Cultural techniques and conditions influencing growth and sporulation of Cercospora zeae-maydis and lesion development in corn. Phytopathology 73:286-289.

2. Borchardt, D. S., Welz, H. G., and Geiger, H. H. 1998. Genetic structure of Setosphaeria turcica populations in tropical and temperate climates. Phytopathology 88:322-329.

3. Chupp, C. 1953. A Monograph of the Fungus Genus Cercospora. Ronald Press Co., Ithaca, NY.

4. Dunkle, L. D., and Carson, M. L. 1999. Genetic variation in Cercospora and the potential impact on selecting for resistance to gray leaf spot of corn. Proc. 53rd Corn Sorghum Res. Conf. 53:334-346.

5. Jenns, A. E., Daub, M. E., and Upcurch, R. G. 1989. Regulation of cercosporin accumulation in culture by medium and temperature manipulation. Phytopathology 79:213-219.

6. Latterell, F. M., and Rossi, A. E. 1983. Gray leaf spot of corn: A disease on the move. Plant Dis. 67:842-847.

7. Levy, M., Correa-Victoria, F. J., Zeigler, R. S., Xu, S., and Hamer, J. E. 1993. Genetic diversity of the rice blast fungus in a disease nursery in Colombia. Phytopathology 83:1427-1433.

8. Mayr, E. 1942. Systematics and the Origin of Species. Columbia University Press, New York.
9. Mayr, E. 1970. Populations, Species, and Evolution. An Abridgment of Animal Species and Evolution. Belknap Press, Cambridge, MA.

10. McGee, D. C. 1988. Maize Diseases: A Reference Source for Seed Technologists. The American Phytopathological Society, St. Paul, MN.

11. Pringle, R. B., and Scheffer, R. P. 1963. Purification of the selective toxin of Periconia circinata. Phytopathology 53:785-787.

12. Taylor, J. W., and Natvig, D. 1986. Isolation of fungal DNA. Pages 252258 in: Zoosporic Fungi in Teaching and Research. M. S. Fuller and S. A. Jaworsky, eds. Southeastern Publishing Company, Athens, GA.

13. Tehon, L. R., and Daniels, E. 1925. Notes on the parasitic fungi of Illinois. Mycologia 17:240-249.

14. Wang, J., Levy, M., and Dunkle, L. D. 1998. Sibling species of Cercospora associated with gray leaf spot of maize. Phytopathology 88:12691275.

15. Ward, J. M. J., Liang, M. D., and Rijkenberg, F. H. J. 1997. Frequency and timing of fungicide applications for the control of gray leaf spot in maize. Plant Dis. 81:41-48.

16. Ward, J. M. J., and Nowell, D. C. 1998. Integrated management for the control of maize gray leaf spot. Integr. Pest Manage. Rev. 3:1-12.

17. Ward, J. M. J., Stromberg, E. L., Nowell, D. C., and Nutter, F. W., Jr. 1999. Gray leaf spot: A disease of global importance in maize production. Plant Dis. 83:884-895.

18. White, T. J., Bruns, T., Lee, S., and Taylor, J. 1990. Amplification and direct sequencing of fungal ribosomal RNA genes for phylogenetics. Pages 315-322 in: PCR Protocols, a Guide to Methods and Applications. M. A. Innis, D. H. Gelfand, J. J. Sninsky, and T. J. White, eds. Academic Press, Inc., San Diego, CA.

19. Zolan, M. E., and Pukkila, P. J. 1986. Inheritance of DNA methylation in Coprinus cinereus. Mol. Cell. Biol. 6:195-200. 